Edunomika - Vol. 04, No. 02 (Agustus, 2020)

\title{
PENGARUH KOMPETENSI, REWARD DAN PENGEMBANGAN KARIR TERHADAP KINERJA DOSEN STIE TRISNA NEGARA
}

\author{
Helisia Margahana \\ STIE Trisna Negara, Belitang, OKU Timur \\ Email: helisiagaraika87@gmail.com
}

\begin{abstract}
Abstrak : Tujuan dari penelitian ini adalah untuk mengetahui dan membuktikan pengaruh dari variabel independen yaitu kompetensi, reward dan pengembangan karir terhadap variabel dependen yaitu kinerja dosen STIE Trisna Negara secara simultan dan parsial. Metodologi dari penelitian ini menggunakan diskriptif kuantitatif. Penelitian dilakukan di STIE Trisna Negara, Belitang dengan jumlah populasi 55 dan jumlah sampel 45 responden. Metode pengambilan sampel menggunakan sampel jenuh. Pengukuran dalam kuesioner menggunakan skala Likert. Metode analisis data yang digunakan dalam penelitian ini adalah uji instrumen, uji asumsi klasik dan pengujian hipotesis (analisis regresi linear berganda, uji F, uji t, dan koefisien determinasi) dengan bantuan program SPSS versi 24. Hasil dari penelitian ini menunjukkan bahwa variabel kompetensi, reward dan pengembangan Karir berpengaruh positif secara simultan terhadap kinerja dosen STIE Trisna Negara, Belitang. Kompetensi secara parsial berpengaruh positif dan signifikan. Sedangkan Reward dan Pengembangan karir secara parsial tidak berpengaruh terhadap kinerja Dosen STIE Trisna Negara.
\end{abstract}

Kata kunci: Kinerja, Kompetensi, Pengembangan Karir, Reward.

Abstract : The purpose of this study was to determine and prove the effect of the independent variables, namely competence, reward and career development, on the dependent variable, namely the performance of Lecturer STIE Trisna Negara simultaneously and partially. The methodology of this research uses quantitative descriptive. The research was conducted at STIE Trisna Negara, Belitang with a population of 55 and a total sample of 45 respondents. The sampling method uses saturated samples. Measurement in the questionnaire uses a Likert scale. The data analysis method used in this research is instrument test, classical assumption test and hypothesis testing (multiple linear regression analysis, $F$ test, $t$ test, and coefficient of determination) with the help of SPSS version 24 program. The results of this study indicate that the competency variable, rewards and career development have a positive effect simultaneously on the lecturer performance of STIE Trisna Negara, Belitang. Competence partially has a positive and significant effect. Meanwhile, rewards and career development partially do not affect the performance of STIE Trisna Negara lecturers.

Keywords: Performance, Competence, Career Development, Reward. 


\section{Edunomika - Vol. 04, No. 02 (Agustus, 2020)}

\section{PENDAHULUAN}

Sumber daya manusia memiliki peran yang sangat penting dalam suatu perusahaan. Sumber daya manusia dapat membuat sumber daya yang lainnya mampu berfungsi dengan baik. Melalui sumber daya manusia profesional, memiliki mental yang baik, efektif dan memiliki kinerja yang tinggi, hal ini mengharuskan pihak pimpinan perusahaan harus bisa menemukan cara terbaik untuk mendayagunakan sumber daya manusia disuatu perusahaan supaya tujuan yang diinginkan bisa tercapai. (Gusnetti, 2014). Selanjutnya Ernur (2017) menunjukan, bahwa keberhasilan dari suatu perusahaan dipengaruhi oleh banyak faktor.

Hasil penelitian Tangkuman (2015) juga mengatakan bahwa setiap organisasi atau perusahaan harus memiliki susun rencana terbaik untuk bersaing, khususnya dalam meningkatkan kinerja para karyawan, dengan cara melakukan penilaian kinerja, penilaian kompetensi yang dimiliki karyawan dan pemberian reward. Sudah menjadi tugas manajer perusahaan untuk memperhatikan aspek penting ini. Selanjutnya menurut penelitian Kartika dan Sugiarto (2014) kinerja karyawan tidak terlepas dari kompetensi yang dimiliki karyawan. Kompetensi menjadi modal awal yang ada dalam diri setiap karyawan untuk menduduki jabatan dan melaksanakan pekerjaan sesuai dengan tanggung jawab dan tugas yang diembannya. Memiliki karyawan yang berkompetensi, maka untuk kinerjanya juga bisa lebih optimal, dengan begitu maka ke efisiensi dan efektifitas Sumber Daya Manusia juga akan ikut meningkat.

Demi meningkatkan kinerja karyawan, maka suatu organisasi penting melakukan identifikasi sesuai kebutuhan agar bisa menerapkan pengembangan karir karyawan. Sesuai hasil dari penelitian Massie (2015) menyatakan bahwa pengembangan karir sangat berpengaruh secara positif terhadap kinerja karyawan.

Banyaknya aspek pengaruh kinerja pada karyawan, maka peneliti tertarik untuk melakukan penelitian lebih komperehensif dengan mengambil judul "Analisis kompetensi, reward dan pengembangan karir terhadap kinerja dosen di STIE Trisna Negara, Belitang.

\section{METODOLOGI PENELITIAN}

Pendekatan penelitian yang digunakan adalah pendekatan kuantitatif, yaitu menekankan pada data-data angka yang diolah menggunakan aplikasi SPSS versi 24, sehingga diperoleh signifikansi hubungan antar variabel yang diteliti. Penelitian ini dilakukan dengan tujuan untuk mendapatkan bukti pengaruh antara variabel bebas, yaitu kompetensi, reward dan pengembangan karir terhadap variabel terikat, yaitu kinerja dosen STIE Trisna Negara, Belitang.

Populasi dalam penelitian ini merupakan dosen yang ada di STIE Trisna Negara. Teknik pengambilan sampel menggunakan teknik sampling jenuh dengan jumlah 90 orang. Diantara 55 sampel yang digunakan terjadi biasdata, sehingga menyebabkan data tidak normal, selanjutnya

peneliti mensortir beberapa kuisioner untuk sampel jenuh, sehingga diperoleh data sebanyak 45 sampel.

Variabel dalam penelitian dikelompokan menjadi 2, yaitu variabel independen yaitu kompetensi $\left(\mathrm{X}_{1}\right)$, reward $\left(\mathrm{X}_{2}\right)$ pengembangan karir $\left(\mathrm{X}_{3}\right)$ dan variabel dependen yaitu kinerja dosen 
(Y). Teknik pengumpulan data dalam penelitian ini berupa observasi, kuesioner dan wawancara. Kuesioner penelitian diukur menggunakan skala pengukuran likert dengan jawaban sangat setuju diberi skor 5, setuju 4, kurang setuju 3, tidak setuju 2 dan sangat tidak setuju diberi skor 1.

Teknik analisis data yang digunakan terdiri dari uji validitas, uji reliabilitas, uji normalitas data, uji multikolinieritas, uji heteroskedastisitas, uji autokorelasi, regresi linear berganda, uji t, uji $\mathrm{F}$, analisis determinasi melalui bantuan program SPSS versi 24.

\section{HASIL DAN PEMBAHASAN}

a. Variabel Kompetensi

Hasil perhitungan diperoleh hasil nilai dengan tingkat signifikansi variabel kompetensi sebesar ,000 atau kurang dari 0,05, artinya terdapat pengaruh yang signifikan antara kompetensi terhadap kinerja dosen di STIE Trisna Negara Belitang. Adanya program studi lanjut dan pelatihan khusus untuk dosen di STIE Trisna Negara Belitang menjadikan para dosen memiliki kompetensi yang sesuai dengan posisi kerjanya. Hal ini memberikan pengaruh positif terhadap kinerja dosen di STIE Trisna Negara Belitang.

b. Variabel Reward

Hasil perhitungan diperoleh hasil nilai dengan tingkat signifikansi variabel reward sebesar 0,617 atau lebih besar dari 0,05, artinya tidak terdapat pengaruh yang signifikan antara reward terhadap kinerja dosen di STIE Trisna Negara Belitang. Hasil penelitian mengidentifikasi bahwa variabel reward masih tergolong rendah. Hal ini disebabkan karena reward yang ada di STIE Trisna Negara Belitang hanya berupa tunjangan bulanan, uang transport, uang makan dan bonus bagi dosen yang ditugaskan di luar kota, sehingga pemberian reward dianggap kurang adil, karena tidak semua dosen mendapatkan kesempatan untuk bertugas di luar kota. Oleh sebab itulah penyebab dari ketidaksignifikan dari variabel reward terhadap dosen di STIE Trisna Negara Belitang. Seperti penelitian yang telah dilakukan oleh Purnomo (2018) bahwa variabel reward tidak berpengaruh secara signifikan terhadap kinerja pegawai.

c. Pengembangan Karir

Hasil perhitungan diperoleh hasil nilai dengan tingkat signifikansi variabel pengembangan karir sebesar 0,121 atau lebih besar dari 0,05, artinya tidak terdapat pengaruh yang signifikan antara pengembangan karir terhadap kinerja dosen di STIE Trisna Negara Belitang. Setiap saat, Kementerian Pendidikan dan Kebudayaan melalui LLDIKTI memberikan kesempatan pelatihan kepada seluruh dosen dan mendorong STIE Trisna Negara Belitang untuk mengajukannya. Ada beberapa ketentuan yang harus dipenuhi oleh para dosen yang ingin mengembangkan karirnya, sehingga bagi para dosen yang tidak masuk dalam kategori dan ketentuan menjadi penghambat untuk berkembang. Selain itu banyak pula para dosen yang berada di zona nyaman dengan posisi yang saat ini dimiliki. 


\section{SIMPULAN}

Berdasarkan dari analisis data yang sudah diuraikan ditas, maka peneliti memberikan kesimpulan sebagai berikut ini:

1) Hasil dari Uji F menunjukan bahwa secara simultan atau secara bersama-sama variabel kompetensi, reward dan pengembangan karir berpengaruh signifikan terhadap kinerja dosen di STIE Trisna Negara Belitang.

2) Hasil dari uji t (uji parsial) menunjukan bahwa:

a. Kompetensi berpengaruh positif dan signifikan terhadap kinerja dosen di STIE Trisna Negara Belitang. Hal ini dikarenakan STIE Trisna Negara Belitang memberikan pelatihan dan peningkatan pendidikan bagi para dosen untuk meningkatkan kompetensi sesuai dengan bidang ilmu atau posisi kerjanya.

b. Reward tidak berpengaruh terhadap kinerja dosen di STIE Trisna Negara Belitang. Hal ini dikarenakan pemberian reward dianggap kurang adil bagi setiap dosen di STIE Trisna Negara Belitang. Reward bisa berupa seperti tunjangan bulanan dengan nominal yang tidak sama antara dosen yang satu dengan yang lainnya, karena tergantung pada posisi dosen. Pemberian reward yang berupa bonus hanya diberikan kepada para pegawai yang mendapatkan tugas keluar kota. Sedangkan tidak semua dosen mendapatkan kesempatan tugas keluar kota, sehingga hanya dosen tertentu saja yang bisa mendapatkan bonus tersebut.

c. Pengembangan karir tidak berpengaruh terhadap kinerja dosen di STIE Trisna Negara Belitang. Banyak dosen yang sudah merasa berada di zona nyaman, sehingga membuat para dosen merasa bahwa karirnya yang semakin tinggi tidak terlalu berpengaruh. Meskipun setiap saat Kementerian Pendidikan dan Kebudayaan memberikan kesempatan untuk mengajukan kenaikan jabatan fungsional dan pangkat/golongan, namun hanya dosen yang masuk dalam kriteria saja yang bisa mengembangkan jenjang karirnya lebih tinggi.

\section{DAFTAR PUSTAKA}

Gusnetti. (2014). Faktor - Faktor Yang Mempengaruhi Kinerja Karyawan Pada PT. Garuda Indonesia Pekanbaru. Jom FISIP Vol. 1 No. 2.

Kartika, Nurbani Lucia, Sugiarto Agus, (2015). "Pengaruh Tingkat Kompetensi Terhadap Kinerja Pegawai Administrasi Perkantoran”. Volume XVII No. 1.

Massie, Renaldy, (2015). "Pengaruh Perencanaan Karir, Pelatihan dan Pengembangan Karir Terhadap Kinerja Pegawai Pada Museum Negeri Provinsi Sulawesi Utara". Jurnal Berkala Ilmiah Efisiensi Volume 15 No. 05.

Massie, Renaldy, dkk, 2015. "Pengaruh Perencanaan Karir, Pelatihan dan Pengembangan Karir Terhadap Kinerja Pegawai Pada Museum Negeri Provinsi 
Tangkuman, Kevin, (2015). "Penilaian Kinerja, Reward, dan Punishment Terhadap Kinerja Karyawan Pada PT. Pertamina (Persero) Cabang Pemasaran Suluttenggo”. Jurnal EMBA 885 Vol.3 No.2, hal. 884-895.

Shaputra, A. R., \& Hendriani, S. (2015). Pengaruh Kompetensi, Komitmen Dan Pengembangan Karir Terhadap Kinerja Karyawan PT. Bank Rakyat Indonesia (Persero) Kantor Wilayah Pekanbaru. Jurnal Tepak Manajemen Bisnis, 7(1), 1-17. 